\title{
German science in danger as hope for big increase fades
}

\section{Bonn/Heidelberg}

BEGGing for money is not Hubert Markl's favourite activity. But Markl, the president of the Deutsche Forschungsgemeinschaft (DFG), went before a group of West German parliamentarians in Bonn on 8 June to plead his case for a 5 per cent increase in the DFG budget for 1989.

The increase is especially crucial in view of the large number of university graduates expected in the coming years, a result of the postwar birth bulge.

Unlike some politicians, Markl views the abundance of new graduates as a "gold reserve". But he warned the Bundestag that if graduates who want to enter basic research are not supported right away, they will be lost to the universities.

The DFG, which funds basic research in West German universities, is supported

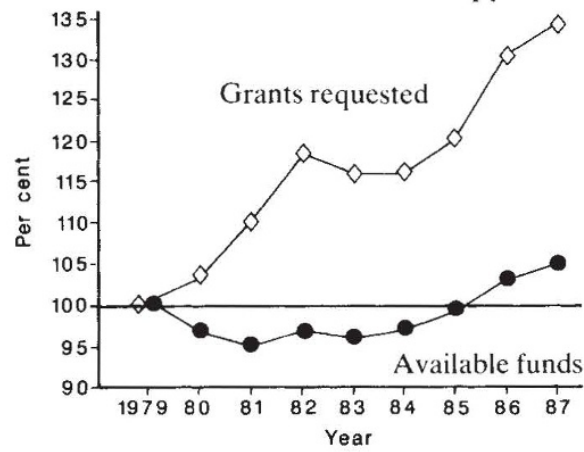

by the federal and Länder (state) governments, both of which must agree on the budget. The finance ministers of the Länder proposed an increase of only 2.5 per cent to the annual DFG budget of DM1,100 million, despite Markl's visits to the political chiefs of most of the eleven Länder within the past year.

But the Länder may be persuaded to increase their contribution if the federal government will go along. Delicate negotiations between Education Minister Jürgen Möllemann and Finance Minister Gerhard Stoltenberg may yield a higher federal contribution. But if this attempt fails, the DFG will take its case before the West German cabinet in early July. This, according to sources within the DFG, will be the best chance for an increase.

Chancellor Helmut Kohl's centre-right coalition is now busy trying to reach a compromise on larger-scale issues such as welfare, tax and pension reform as well as the research budget before the parliamentary recess begins on 8 July.

Even a 5 per cent increase would not come close to maintaining the ratio of DFG grants to applications, said Markl. The money requested in grant applications has grown by more than 10 per cent a year while the budget has remained almost constant in real terms (see graph).
There is particularly strong competition for grants in biomedical and hightechnology areas of research, areas which are economically important for West Germany.

At the same time, he reminded the Bundestag members that several thousand more university graduates will be seeking doctoral and postdoctoral support from the DFG for each of the next several years.

Markl said that the "bare minimum" at which the DFG can continue to fund all the superior grant applications for both graduate stipends and project support is a 5 per cent increase in 1988, followed by 5.5 per cent in each of the next two years. The DFG budget had already fallen short of those expectations by the time of his statement, having received 3 per cent for 1988 .

If the DFG is granted 5 per cent in 1989 , "we will put all of it into supporting young researchers", said Markl. The increase would "send a sign to the students" and encourage them to continue applying for support. The influential Wissenschaftsrat and Kultusministerkonferenz as well as the Education Ministry support this rationale, he said.

Markl mentioned the example set in Switzerland, where the Nationalfond, the DFG's counterpart, has been granted an annual budget increase of 3.8 per cent over the next three years because of a similar demographic bulge.

The Max Planck Society (MPG), which has received slightly larger increases than the DFG in recent years, is having budget troubles too. MPG president Heinz Staab announced at the society's annual conference that a resolution passed by the Bundestag budget committee last year may reduce the MPG budget for 1988. In addition, a long-awaited equipment replacement programme was postponed again until at least 1989 .

Staab called the threatened cuts "incomprehensible" in the light of the unanimous support that the federal and Länder governments had declared for the MPG last year.

A representative of industry, Hermann Freudenberg, who was present on 8 June, implored Bundestag members to grant the DFG's request. The DFG budget is tiny, he said, in comparison to the DM41,000 million spent in 1987 on public support of research and development. But Bundestag budget committee member Karl Diller (Social Democrat) painted a gloomy picture of the prospects of squeezing out a few extra million for the DFG. Mercy, if it arrives, will have to come from the top.

\section{Ariane-4 launched successfully}

Paris

EuROPE's new Ariane-4 commercial rocket launcher successfully put its payload of three satellites into orbit on 15 June, only six minutes behind schedule (see Nature $333,591 ; 1988)$. This demonstration flight, which initially was to carry ballast only, not only helps Arianespace - the European consortium operating Ariane - to reduce its backlog of orders. It was also an essential reinforcement for Europe's determination to hold onto its 50 per cent share of world commercial launches in the face of the United States' imminent comeback, the entry of the Soviet Union into the market and competition from the Chinese and Japanese.

The US presence in the commercial launch market was suspended in 1986 when the manned Challenger shuttle tragically exploded shortly after lift-off. Since then, the United States has put only military payloads into space. But the technological experience gained will not be wasted, as Martin Marietta's Titan 3 commercial launcher - Ariane-4's most serious competitor - shares many of the components used in the smaller, military rockets. McDonnell Douglas is also building 20 less-powerful Delta launchers for the US Air Force. Although not a direct competitor, each Delta-2 rocket can separately carry one of the satellites Ariane- 4 will be able to launch in pairs or threes. Ariane-4's multiple payload capacity is an important selling point, necessary to keep costs down and to meet launch deadlines.

Having offloaded development costs onto the defence budget, the United States will undoubtedly be able to offer its launches at cut price - to the chagrin of Arianespace and the European Space Agency (ESA), which have always depended on civil and private-sector investment. What ESA calls the "formidable launch capacity" of Soviet Proton launchers is also being offered to the world commercial market for the first time, again following years of state military investment in development.

If the low cost of Chinese CZ-3 (Long March 3) launches cannot easily be countered by the Europeans, the Japanese still have nothing to match Ariane-4's 4,200 kg payload capacity. Trends in satellite technology were not well forecast by Japanese constructors, so that the $\mathrm{H} 1$ launcher is already outclassed.

The success of Ariane-4 is also a shot in the arm for France, which provided nearly 60 per cent of the development finance. In the face of recurrent doubts from other European partners, France has consistently placed a high priority on its - and Europe's - presence in space. Peter Coles 